\title{
Proving Abstract Algebra Skills with Problem-Based Learning Integrated with Videos and Worksheets
}

\section{Capacidad Demostrativa de Algebra Abstracta con Aprendizaje Basado en Problemas Integradopor Videos y Hojas de Trabajo}

\author{
Jackson Pasini Mairing* \\ ORCID iD 0000-0002-9133-5775
}

\begin{abstract}
Previous research showed students faced difficulties in solving the given problems in the Abstract Algebra course. The research aimed to describe the effect of the method of problem-based learning integrated with videos and worksheets to improve the proving skills of mathematics education students in one of the universities in Central Kalimantan, Indonesia. The researcher developed and uploaded the videos on YouTube. The research design was an experimental study. The researcher implemented the method in an experimental class. The control class students learned by using the usual method of the past three years that emphasized acquiring the Abstract Algebra concepts. The researcher selected the experimental class randomly. The numbers of students in the experimental and control classes were 32 and 28, respectively. The students of both classes solved the same problems in the post-test at end of the implementation. The post-test contained five problems to prove. The research results showed that the transactive reasoning activities in the experimental class enabled the students to prove at an appropriate abstraction level. The students' scores in the Abstract Algebra for the experimental class were greater than those in the control class. Therefore, the method affected students' ability to solve Abstract Algebra problems.
\end{abstract}

Keywords: Abstract algebra. Problems. Problem-based learning. Videos. Worksheets. YouTube.

\section{Resumo}

Investigaciones anteriores mostraron que los estudiantes enfrentaron dificultades para resolver los problemas dados en el curso de Álgebra abstracta. La investigación tuvo como objetivo describir el efecto del método de aprendizaje basado en problemas, integrado con videos y hojas de trabajo, para mejorar la capacidad de prueba de los estudiantes de educación matemática en Kalimantan Central, Indonesia. El investigador desarrolló y subió los videos a YouTube. El diseño de la investigación fue un estudio experimental. El investigador implementó el método en una clase experimental. Los alumnos de la clase de control aprendieron utilizando el método habitual de los últimos tres años, que enfatizaba en la adquisición de los conceptos de Álgebra Abstracta. El investigador seleccionó la clase experimental al azar. El número de estudiantes en las clases experimental y de control fue 32 y 28 , respectivamente. Los alumnos de ambas clases resolvieron los mismos problemas en el post-test al final de la implementación. La prueba posterior contenía cinco problemas para probar. Los resultados de la investigación mostraron que las actividades de razonamiento transactivo en la clase experimental permitieron a los estudiantes demostrar en un nivel de abstracción apropiado. Además, las puntuaciones de los estudiantes en Álgebra abstracta en la clase experimental fueron mayores que las del grupo de control. Por lo tanto, el método afectó la capacidad de los estudiantes para resolver problemas de álgebra abstracta.

Palavras-chave: Algebra abstracta. Problemas. Aprendizaje basado en problemas. Videos. Hojas de trabajo. YouTube.

* PhD in Mathematics Education from Universitas Negeri Surabaya (UNESA). Associate Professor of Mathematics Education Department, Faculty of Education and Teacher Training, Universitas Palangka Raya (UPR), Palangka Raya, Central Kalimantan, Indonesia. E-mail: jp-mairing@ math.upr.ac.id. 


\section{Introduction}

Previous studies showed students faced difficulties in solving problems of Abstract Algebra course. Research results from one of the universities in Riau Islands, Indonesia showed that $57.94 \%$ of the students made conceptual mistakes, $33.33 \%$ of them made mistakes due to carelessness, and the rest of them, $8.73 \%$, experienced the computational mistakes when solving the problems (AGUSTYANINGRUM; ABADI; SARI; MAHMUDI, 2018). The causes of the mistakes were that the students were lacking concepts, or had misconceptions of axioms, definitions, or course theorems. The condition also occurred with students at the Mathematics Education Department from one of the universities in South Kalimantan, Indonesia. The number of students who experienced the mistakes was $73.93 \%$ (FITRIA, 2014). Moreover, research results also showed that all students at the Mathematics Education Department from one of the universities in Central Kalimantan, Indonesia were unable to prove all the problems available (MAIRING; SYAHRAN; PANCARITA; SUPARMAN, 2018).

The abstract nature of the course concepts caused the students to have difficulties. Students needed to elaborate knowledge, so they reached some appropriate levels of abstraction, and be able to solve the problems (DUBINSKY; MCDONALD, 2018). The elaborated knowledge also helped students construct mental images of the concepts, understand the problems, develop plans, and see proof paths. The images made the abstract nature of the course become more contextual in their minds (POLYA, 1973; WEBER, 2001).

The elaborated knowledge was as follows. The first knowledge was mental images of the data, targets, and conditions of the problems. The second was the knowledge of approaches or strategies for proving the problems. The first and second were strategic knowledge (WEBER, 2001). The third was an understanding of concepts related to the problems. The fourth was an understanding of problem-solving heuristics. The heuristics were understanding the problem, developing plans, carrying out the plans, and practicing the activities of looking back (POLYA, 1973). The fifth was the knowledge internalized from experiences in solving previous isomorphic problems (MAIRING; BUDAYASA; JUNIATI, 2011).

Lack of knowledge made the students unable to prove the problems (MAIRING, 2017). Examples of the lack of knowledge were as follows. The students were not able to determine the set in the problems, or they were not able to construct appropriate mental images based on a meaningful understanding of concepts related to the problems. They could 
not develop appropriate plans because their experience was limited in proving previous problems. Besides, they did a reducing abstraction level that proved a true statement utilizing the statement which was true for some numbers or some members of the set (DUBINSKY; MCDONALD, 2018). It means the actions chosen and practiced by the students on the group concepts were not integrated into the process. Therefore, the failure in doing the integration prohibited the students to elaborate knowledge (HAZZAN, 1999; TALL, 1999).

Learning Abstract Algebra should enable students to develop the ability to solve problems. They could increase the ability by practicing problem-solving activities in a PBL (problem-based learning) environment. PBL is a learning method in which mathematics problems are the center of students' activities (ARENDS, 2012). The problem itself is a mathematics question in which the solution is not immediately visible to the students (MAIRING, 2018). There are two types of problems, namely a problem to find and a problem to prove. The main goal of the problem to find is to seek a particular object which is unknown to the problem, while the main goal of the problem to prove is to show a statement is either true or false (POLYA, 1981).

The learning activities of the method were as follows. First, the lecturer posed some mathematics problems. Second, students in each group solved the problems cooperatively. Third, a student from each group wrote a solution to the problem and explained it in front of the class. Fourth, the lecturer facilitated class discussion to reflect and evaluate the solutions by asking some metacognitive questions, such as "Why was this particular line like that?", "What were the theorems or axioms used in the line?", or "What were the mathematical truths underlying the line?" Such questions helped students reduce the abstraction level, so they successfully proved the problem at an appropriate level. Fifth, the lecturer also facilitated discussion to develop other means of solving problems. Sixth, the students reached their conclusions (MAIRING, 2018).

The advantages of the method were as follows. The method promoted students' interaction and participation (GRAAFF; KOMOS, 2003; LEAL JUNIOR; ONUCHIC, 2015). Students developed creative thinking by developing different means of solution (BALTACI; YILDIZ; GUVEN, 2014). Also, using the method increased the students' ability to solve the given problems (FATIMAH, 2016; SALSABILA; RATNANINGSIH; HADI, 2015; SARININGSIH; PURWASIH, 2017; SYAFMEN, 2013) and their critical thinking (HAMID, 2012; ROSA; PUJIATI, 2016).

Previous experiences of the researcher, as the lecturer of the course, showed that students needed time to learn Abstract Algebra concepts in class. The students were not able 
to solve problems if they lacked concepts. However, learning activities focused on learning the concepts provided students fewer opportunities to practice problem-solving. The condition could be overcome by bringing students who learned the concepts by themselves out of class time. They used the concepts to solve the problems later in the PBL environment class.

Such learning could be done by using digital media. Students learned to construct an understanding of axioms, definitions, theorems, and proofs of Abstract Algebra by watching videos by themselves on YouTube channels before class time. If there were questions or nonunderstandable concepts in the videos, the students would write them on the question sheets and send them digitally to the researcher before the class meeting. The researcher discussed the questions in the class to overcome the condition. Furthermore, they used the understanding to solve some mathematics problems in the students' worksheets cooperatively. Such learning could improve the quality of learning activities (OKUR; DIKICI; SANALAN; TATAR, 2011; ZAFFAR; QURAISHI; ANSARI, 2013).

The previous problematic conditions in the Abstract Algebra course should be solved by implementing learnings that integrated the PBL method, the digital media (videos), and the worksheets. The research aimed at describing the effect of the implementation to improve students' ability of solving Abstract Algebra problems. The ability was indicated by scores obtained by the students on a test containing the problems. The students came from the Mathematics Education Department in Central Kalimantan, Indonesia in the academic year of 2018/2019. The researcher developed and uploaded the videos on YouTube. The students could learn with the videos anytime and anywhere independently.

Other lectures or researchers could use the learning method of this research to improve students' ability to solve the problems in other courses that contained mathematical problems to prove such as Real Analysis, Linear Algebra, or Graph Theory. The ability to solve the problems is classified as HOTS (higher-order thinking skills) (MAIRING, 2018). The increasing ability will improve the students' thinking skills. Moreover, such learning helps students acquire ways of thinking, confidence in unfamiliar situations, and habits of persistence (NCTM, 2000).

\section{Methods}

The researcher conducted the research in eight stages. They were defining research problems, formulating hypotheses, collecting scores of initial abilities, developing research instruments, implementing the methods in experimental class, conducting post-tests, 
analyzing data, and drawing conclusions (COHEN; MANION; MORRISON, 2007; LODICO; SPAULDING; VOEGTLE, 2006).

\subsection{Research Design}

The research type was an experimental study. The treatment in the experimental class was the PBL method integrated with videos and worksheets symbolized by $\tau_{1}$. The students of the control class learned using a method applied in the past three years, namely the usual method symbolized by $\tau_{0}$, The usual method focused on understanding Abstract Algebra concepts in the class, then the students practiced solving problems in the remaining time. The implemented methods were the independent variable of the research.

The students in both classes used the same module of Abstract Algebra and completed the same post-test. The post-test contained some problems to prove. The post-test score of each student was symbolized by $y_{i j}$ where $i$ was an index for the learning methods $(i=0,1)$, and $j$ was an index for the students. The scores indicated the students' ability to solve problems (dependent variable).

There was an extraneous variable that might influence the dependent variable. The variable was the initial abilities of prerequisite materials of Abstract Algebra. The materials were mathematical logic and number theories. The students learned the materials in Basic Mathematics and Number Theory courses, respectively. The students' average course scores was the initial abilities symbolized by $A_{i j}$. The researcher controlled the extraneous variable by accommodating it into a mathematical model of covariance analysis (LODICO; SPAULDING; VOEGTLE, 2006). The model was

$$
y_{i j}=\mu+\tau_{i}+\beta A_{i j}+\epsilon_{i j}
$$

where $\epsilon_{i j}$ were residuals.

\subsection{Research Instruments}

Research instruments were learning kits and post-test. The experimental class kits were lesson plans, videos, Abstract Algebra modules, students' worksheets, question sheets, and quizzes. The researcher developed and uploaded the videos on jackson mairing's YouTube channel. The worksheets and quizzes contained some problems to prove. The control class kits were lesson plans of the usual method, modules, quizzes, and post-test. 
The learning scenario of the experimental class was as follows.

Preparation

1. The researcher developed and uploaded 26 videos of Abstract Algebra materials on his YouTube channel. The concepts of the videos were group definition, examples or nonexamples of the group, group theorems, subgroup definition, and examples and nonexamples of the subgroup.

2. The researcher divided the students into heterogeneous groups of 4-5 members based on the initial abilities. Each student had numbers 1, 2, 3, 4, or 5.

Before the meeting

1. The students learned the Abstract Algebra concepts by watching the videos on the provided YouTube channel and solved the problems in the worksheets. They wrote nonunderstandable concepts in the question sheets and sent them to the researcher digitally.

2. The researcher posed problems in the worksheets to the students (the first step of PBL).

3. The students in each group discussed the questions and problem solutions in the worksheet. All students had to learn all the solutions (the second step of PBL).

During the meeting

1. The researcher facilitated discussions intended to respond the questions in the sheets.

2. The researcher posed a problem in the worksheet and called students with a certain number in each group to write a solution to the problem. They wrote the solution at the same time on the whiteboard in front of the class. The researcher asked some students to explain the solutions. The researcher facilitated class discussion by posing some metacognitive questions. In addition, the researcher guided the students by asking questions according to Polya's heuristic such as "What was the known facts?", "What was the target?", "What was your plan to prove the problem?", "How did you prove it?", or "How were you sure that the proof was correct?" (the third step of PBL).

3. The researcher facilitated class discussion to evaluate the solutions (the fourth step of PBL), and to develop other means for proving the problems (the fifth step of PBL).

4. The researcher called students several times with different numbers in each group to write and explain the solution of another problem in front of the class. The activities were repeated until all the problems in the worksheet were presented and discussed.

5. Some students concluded the theorems or the solutions (The sixth step of PBL).

6. The researcher informed that Abstract Algebra concepts, videos on YouTube, and problems in the worksheet should be learned or solved by the students before the next meeting. 
The students solved the first and the second quiz at beginning of the third and sixth meetings, respectively. The researcher used the quiz scores to assess the development of students' proving skills. The students reflected on their solutions to the quizzes in the fourth and the seventh meetings. Furthermore, students solved the post-test that contained five problems to prove at the end of the implementation. All students in the experimental and control class solved the same post-test. The problems were as follows.

1. Is the set of $Z$ with operation * defined by $x * y=x y+y$ a group? Explain your answer.

2. Is the set of $Q-\{0\}$ with operations * defined by $x * y=\frac{x y}{3}$ a group? Explain your answer.

3. Let $G$ is an abelian group, and $n$ is a certain integer. Prove that $\left\{a \in G \mid a^{n}=1\right\}$ is a subgroup of $G$.

4. Let $H$ is a subgroup of an abelian group $G$. Prove that $H$ is also an abelian group.

5. Let $H$ and $K$ are subgroups of abelian group $G$. Prove that $H K$ is a subgroup of $G$.

\subsection{Population}

The population was all students at the Mathematics Education Department in one of the universities in Central Kalimantan, Indonesia in the academic year of 2018/2019. They were two classes, A and B, in which the number of students was 32 and 28, respectively. The students having odd identity numbers were in class A, and the others were in class $\mathrm{B}$. The researcher selected the experimental class randomly. The result was class A as the experimental class and the control was class B.

\subsection{Data Collection}

There were two kinds of data in the research, namely the initial abilities, and the posttest scores. The first data was the average of students' scores of two prerequisite courses of Abstract Algebra, namely Basic Mathematics and Number Theory. The scale of the scores was $0-100$. The first course contained a concept of mathematical logic. The second course contained division and module concepts. The second data was students' post-test scores of Abstract Algebra. All students in both classes solved the same post-test. Each solution was scored by a holistic rubric in Table 1 . There were five post-test problems, so the maximum score of each student was $5 \times 4=20$. 
Table 1 - The holistic rubric

\begin{tabular}{cl}
\hline Score & \multicolumn{1}{c}{ Description } \\
\hline 0 & The student does not write anything in the solution sheet. \\
1 & The student writes a solution, but the means of proving is inappropriate or non-understandable. \\
2 & The student writes a solution, the means of proving is not appropriate, but the solution shows some \\
& understanding of the problem or the Abstract Algebra concepts. \\
3 & The student writes a solution, the means is appropriate, but the implementation is not fully correct. \\
4 & The solution is correct
\end{tabular}

Source: Mairing (2018, p. 117-118)

\subsection{Data Analysis}

The researcher analyzed the data using a covariance analysis. The first hypothesis of the analysis was as follows.

$$
\begin{array}{ll}
H_{10}: \beta=0 & \text { (There was no linear relationship between the initial abilities and the } \\
& \text { students' scores of Abstract Algebra) } \\
H_{11}: \beta \neq 0 \quad \text { (There was a linear relationship between the initial abilities and the } \\
\text { students' scores of Abstract Algebra) }
\end{array}
$$

The second hypothesis was as follows.

$$
\begin{array}{ll}
H_{20}: \tau_{0}=\tau_{1}=0 & \begin{array}{l}
\text { (There was no effect of the different treatments on the } \\
\text { students' scores of Abstract Algebra) }
\end{array} \\
H_{21}: \text { at least a } i \text { that } \tau_{i} \neq 0 \quad & \begin{array}{l}
\text { (There was an effect of the different treatments on the } \\
\text { students' scores of Abstract Algebra) }
\end{array}
\end{array}
$$

The researcher examined the assumptions of the analysis before concluding the hypotheses. The assumptions were the extraneous variable (the initial abilities) being independent from the treatments, normal distribution of residuals, homogeneity of variances, and linearity of the model (RUTHERFORD, 2001). The first assumption was satisfied because the experimental class was selected randomly, so the treatment in the selected class did not affect the extraneous variable. The researcher used the Kolmogorov-Smirnov's test, Levene's test, and lack-of-fit test to examine the second, third, and fourth assumptions, respectively. The researcher used Minitab 18 to examine the assumptions and to draw conclusions from the covariance analysis.

\section{Results}

Descriptions of the results were divided into learning activities and students' scores. 


\subsection{Learning Activities}

Before the meeting, the students in the experimental class learned Abstract Algebra concepts by watching the videos on YouTube and then solved the problems in the worksheets by themselves. The appearance of one of the videos could be seen in Figure 1. The students wrote some questions about the videos in the question sheet. One of the student's questions of videos of 19 and 20 could be seen in Figure 2.

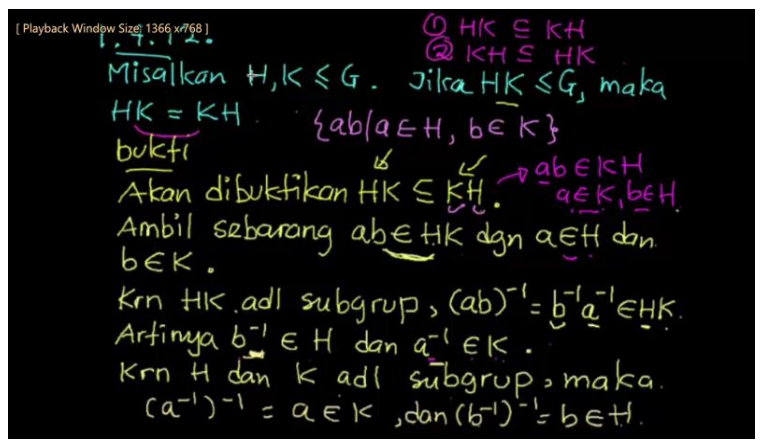

Figure 1 - Appearance one of the videos Source: Prepared by the author

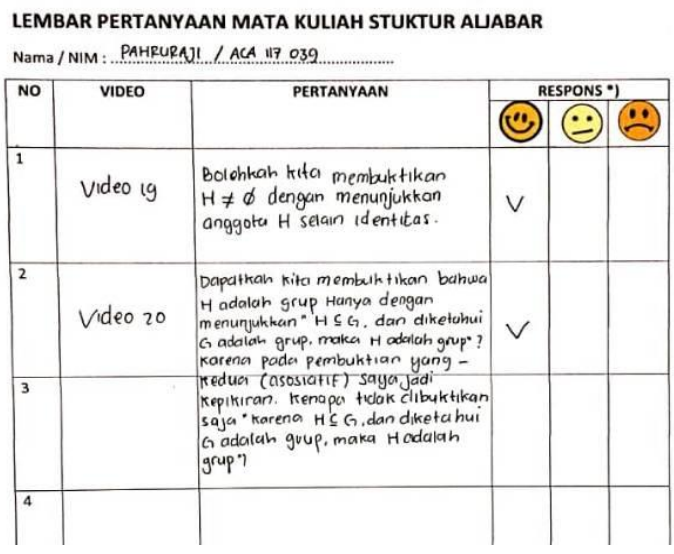

Figure 2 - One of the student's questions in the question sheet Source: Prepared by the author

The questions were as follows (translated into English).

In video 19: "Can we proof $H \neq 0$ by showing that $H$ has an element but it is not the identity?"

In video 20: "Can we prove that $H$ is a group only by showing that $H \subseteq G$, because I think, based on the second axiom (associative axiom) we can prove that $H$ is group since $H \subseteq G$ and $G$ is a group?"

Then, the students discussed the questions and the solutions in their groups.

In the experimental class meeting, the researcher facilitated discussion to respond the questions in the sheets. Then, the researcher called the students with a certain number in each 
group to write and explain the solution in front of the class and facilitated class discussions to reflect the solutions. In the 3rd and 6th meetings, the researcher administered quiz 1 and 2, respectively. The problems in the quizzes were as follows.

Quiz 1: Let $G$ is a group. Show that if $x^{2}=1$ for all $x \in G$, then $G$ is abelian.

Quiz 2: Let $A$ is a subgroup of $B$, and $B$ is a subgroup of $C$. Prove that $A$ is a subgroup of $C$.

\subsection{The Students' scores}

The research results showed the averages of the initial skills of the control and the experimental class were relatively the same. They were 67.20 and 67.47 , respectively. However, the mean of Abstract Algebra scores in the experimental class $(=8.56)$ was greater than the control $(=6.21)$. If the scores were converted to a scale of $0-100$, they were 42.8 and 31.05 , respectively.

Table 2 - Summary of statistics of the initial abilities and the scores

\begin{tabular}{lcccccccc}
\hline Variable & Groups & N & Mean & StDev & Variance & Minimum & Median & Maximum \\
\hline Initial Abilities & Control & 28 & 67.20 & 9.28 & 86.15 & 43.50 & 68.44 & 83.00 \\
(scale of 0-100) & Experiment & 32 & 67.47 & 6.00 & 36.02 & 56.06 & 67.74 & 83.54 \\
Abstract Algebra & Control & 28 & 6.21 & 1.97 & 3.88 & 5.00 & 5.00 & 12.00 \\
(scale of 0-20) & Experiment & 32 & 8.56 & 4.52 & 20.38 & 5.00 & 6.00 & 20.00 \\
\hline
\end{tabular}
Source: Prepared by the author

The same condition also occurred at the maximum scores. The maximum scores of the initial skills in the experimental and the control class were relatively the same. They were 83.54 and 83, respectively. Moreover, there was a student in the experimental class who had a maximum score of 20, whereas there was no such student in the control class (see Table 2).

The researcher examined the assumptions of the covariance analysis before carrying out the analysis. The result of the Kolmogorov-Smirnov's normality test of residuals was $p-$ value $=0.046>0.01=\alpha$, which meant the residuals had normality distribution with a confidence level of $99 \%$ (see Figure 3). The result of the Levene's test of variances homogeneity was $p$-value $=0.014>0.01=\alpha$, which meant the variances were homogeneous with a confidence level of $99 \%$ (see Figure 4). The result of the lack-of-fit test to examine linearity assumption was $p$-value $=0.705>0.01=\alpha$, which meant the model was linear with a confidence level of $99 \%$ (see Table 3). Therefore, the data had satisfied all assumptions of a covariance analysis. 


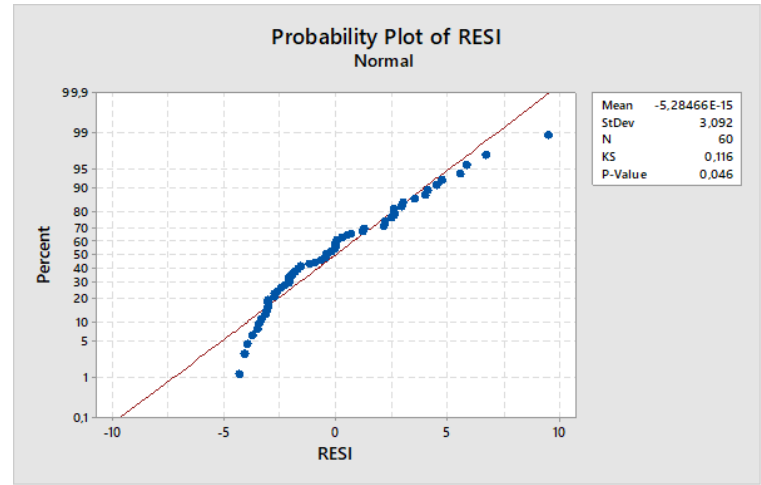

Figure 3 - Result of Kolmogorov-Smirnov's test Source: Prepared by the author

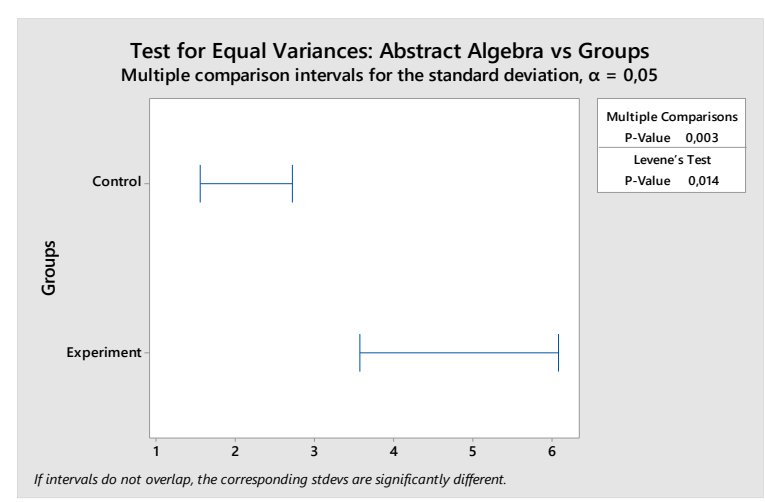

Figure 4 - Result of Levene's test Source: Prepared by the author

Table 3 - The result of covariance analysis

\begin{tabular}{cccccc}
\hline & DF & Adj SS & Adj MS & F-Value & P-Value \\
\hline Initial Abilities & 1 & 172.42 & 172.418 & 17.42 & 0.000 \\
Groups & 1 & 78.08 & 78.084 & 7.89 & 0.007 \\
Error & 57 & 564.17 & 9.898 & & \\
Lack-of-Fit & 55 & 539.67 & 9.812 & 0.80 & 0.705 \\
Pure Error & 2 & 24.50 & 12.250 & & \\
Total & 59 & 818.93 & & & \\
\hline
\end{tabular}

Source: Prepared by the author

The result of the covariance analysis for the initial skills was $p$-value $=0<$ $0.01=\alpha$, which meant there was a linear relationship between the initial abilities and the scores of Abstract Algebra with a confidence level of 99\% (see Table 3). The relationship was positively indicated by the positive coefficient of the initial abilities in the regression equations of the experimental and the control class. The coefficient was 0.2238 (see Figure 5). The positive relationship meant the increasing initial abilities caused the increase in the Abstract Algebra scores.

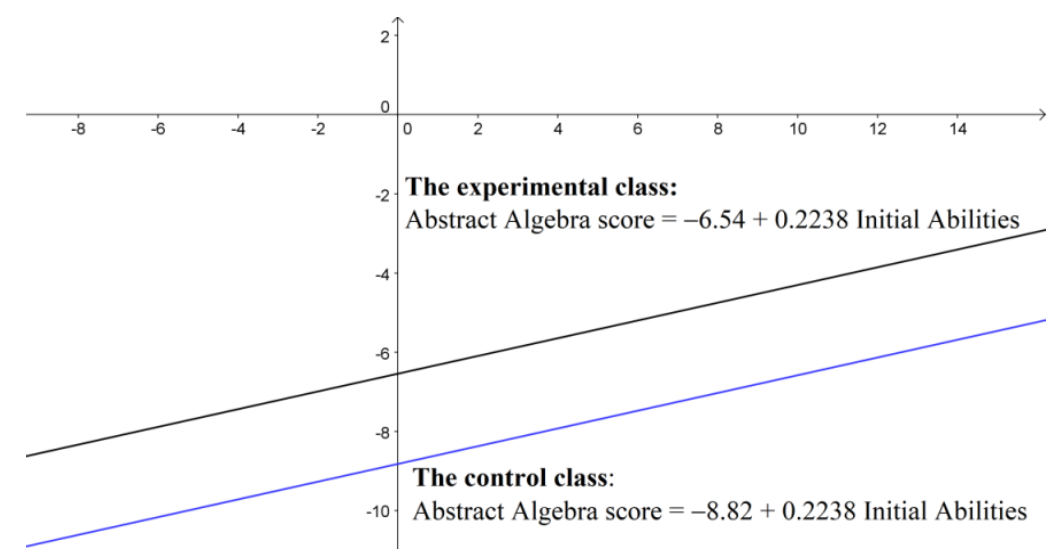

Figure 5 - The regression equations of the experimental and control classes Source: Prepared by the author

The result of the covariance analysis of the treatment (Groups) was $p$-value $=$ $0.007<0.01=\alpha$, which meant there was an effect of different treatment to the students' scores of Abstract Algebra with a confidence level of 99\% (see Table 3). The effect was also 
indicated by the position of the regression line of the experimental class was higher than it was in the control (see Figure 5). The Tukey's comparison test also showed the effect of different treatments, in which the scores of students in the experimental class were greater than those in the control with a confidence level of $99 \%$ (see Table 4). Thus, there was an effect of implementing the learning integrated with the PBL method, the videos, and the worksheets to improve students' ability to solve problems of Abstract Algebra.

Table 4 - Grouping information using the Tukey's method and 99\% confidence

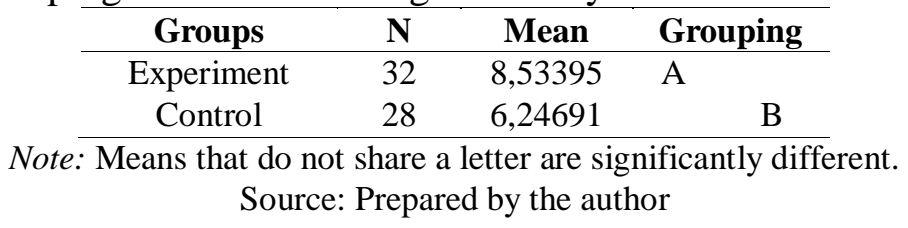

One of the factors of students' difficulties to solve problems was the reducing abstraction level. The research result showed $17.9 \%$ of the students in the control class reduced the abstraction level, whereas $4.8 \%$ of the students in the experimental class did the same. Therefore, the number of students who did the reduction in the experimental class was less than in the control class.

\section{Discussions and Conclusion}

The learning emphasized on acquiring knowledge of concepts and theorems in Abstract Algebra class was not enough for students to develop the ability to solve problems. Similarly, learning that gave students more time to practice solving problems, but was also not enough (WEBER, 2001). In other words, learning should focus on acquiring knowledge and practicing solving problems to improve their ability. However, such learning was timeconsuming.

The solution in this research was to implement the learning using the PBL method integrated with videos and worksheets. The students in the experimental class learned the materials of Abstract Algebra repeatedly using the videos at anytime and anywhere without being bound by the limitation of time and place (RAHARJO, 2014), and they also solved problems in the worksheets before attending the class. The activities in the class focused to discuss and internalize the solutions in their understanding. Previous research showed that such activities could increase students' motivation and ability to solve problems (FATIMAH, 2016; RACHMAWATI; INDRARINI; FUAD; WULANDARI; MULYANTO, 2020; ROSA; PUJIATI, 2016; SINDU; PARAMARTHA, 2018; PRASTITI, 2020). Whereas the students in 
the control class learned by the usual method emphasized on acquiring knowledge of definitions, axioms, and theorems of Abstract Algebra. The research showed Abstract Algebra scores of the students in the experimental class were greater than those in the control class with a $99 \%$ of confidence level. Thus, PBL integrated with videos and worksheets affected students' ability to solve proof problems.

The skills improved through the activities of transactive reasoning covering the ability to explain, clarify, justify, and elaborate the knowledge (SALSABILA; RATNANINGSIH; HADI, 2015). The students in the experimental class did the activities during the class presentations. First, the students of each group wrote their solutions in front of the class. Second, some students explained the solutions. Third, the researcher or the students asked some metacognitive questions. The questions were intended to encourage the students to clarify and justify their solutions. Fourth, the researcher encouraged the students to elaborate their knowledge to develop different means of solutions.

Those activities of solving various problems helped the students in the experimental class to have a less reducing abstraction level. An example of the reduction was that the students prove a set with an operation to be a group by using some numbers or some members of the set during the class presentation. The researcher asked some metacognitive questions to the students. Then, the researcher also asked the same questions to a student who was able to prove the problems. The activities created cognitive conflict among the students. Reflecting on the activities helped the students prove at an appropriate level of abstraction. The research result showed the number of students in the experimental class experiencing the reduction is less frequent than in the control class. Furthermore, creating such cognitive conflict could improve the mathematical reasoning ability of the students when learning Abstract Algebra. The improvement affected the students' ability to prove problems (ILYAS; BASIR, 2016).

The increase on the ability was because the students actively constructed meaningful understanding by themselves through learning using the modules and videos. The activities were shown by all students sent the question sheets before each meeting. Furthermore, all students learned to solve problems in the worksheets and discussed the solutions in their groups. Each student had to learn all solutions in the discussion because the researcher would call all students with a certain number in each group to write the solution of a problem and justify the solution in front of the class. Such learning encouraged students to be actively involved in constructing the understanding and improved their learning outcomes (MAIRING, 2020).

However, the average of Abstract Algebra scores of the experimental class was greater 
than of the control class, but the average was less than the passing grade of 60 (scale of $0-100)$. In the experimental class, the average was 42.8 so the average should be increased at least $17.2(=60-42.8)$. If it were converted to a scale of $0-20$, it would become 3.44 . The research result indicated the initial abilities affected the Abstract Algebra scores. The regression equation represented the effect was Abstract Algebra $=-6.54+0.2238 \times$ initial abilities. If the Abstract Algebra should increase to at least 3.44, then the initial abilities should increase to at least $15.37(=3.44 / 0.2238)$. Therefore, the average score in Basic Mathematics and Number Theory courses should increase to at least 15.37 (scale of 0-100). The research results reinforced theories stating that preexisting knowledge in the students' mind affected their understanding of new knowledge (SKEMP, 1982; STERNBERG; STERNBERG, 2012).

The method of PBL integrated with videos and worksheets should be implemented consistently, so the students can have the ability to solve problems. Further research aiming to improve the ability to some certain targeted numbers needs to be done. For example, the average of students' scores of Abstract Algebra in the control class was 6.21. Some research aiming to increase the average by at least $5.79(=12-6.21)$ needs to be conducted in the future. The value of 12 was the passing grade of 60 converted into a scale of $0-20$. Also, research implementing the method in other courses that have the same characteristics as Abstract Algebra, such as Linear Algebra, Real Analysis, or Graph Theory will be carried out in the future.

\section{References}

AGUSTYANINGRUM, N.; ABADI, A. M.; SARI, R. N.; MAHMUDI, A. An analysis of students' error in solving abstract algebra tasks. Journal of Physics: Conference Series, Yogyakarta, v. 1097, n. 012118 , p. 1-12, 2018.

ARENDS, R. I. Learning to teach. 9. ed. New York: The McGraw-Hill Companies, 2012.

BALTACI, S.; YILDIZ, A.; GUVEN, B. Knowledge types used by eight grade gifted students while solving problems. Bolema, Rio Claro, v. 28, n. 50, p. 1.032-1.055, 2014.

COHEN, L.; MANION, L.; MORRISON, K. Research methods in education. 6. ed. New York: Routledge, 2007.

DUBINSKY, E.; MCDONALD, M. A. APOS: A constructivist theory of learning in undergraduate mathematics education research. In: HOLTON, D.; ARTIGUE, M.; KIRCHGRABER, U.; HILLEL, J.; NISS, M.; SCHOENFELD, A. (Eds.). The teaching and learning of mathematics at university level: New ICMI study series volume 7. Dordrecht: Springer, 2018. p. 275-282. 
FATIMAH, F. Pengaruh pembelajaran berbasis masalah terhadap kemampuan pemecahan masalah matematis mahasiswa universitas Al Asyariah Mandar. Pepatudzu, Polewali, v. 11, n. 1, p. 43-50, 2016.

FITRIA, A. Miskonsepsi mahasiswa dalam menentukan grup pada struktur aljabar menggunakan certainty of response index (CRI) di jurusan pendidikan matematika IAIN Antasari. JPM IAIN Antasari, Banjarmasin, v. 1, n. 2, p. 45-60, 2014.

GRAAFF, E. D.; KOMOS, A. Characteristics of problem based learning. The International Journal of Engineering Education, Ontario, v. 19, n. 5, p. 657-662, 2003.

HAMID, H. Penerapan pembelajaran berbasis masalah dalam meningkatkan keterampilan berpikir kreatif mahasiswa program studi pendidikan matematika FKIP Unkhair. Delta-Pi, Ternate, v. 1, n. 1, p. $52-58,2012$.

HAZZAN, O. Reducing abstraction level when learning abstract algebra concepts. Educational Studies in Mathematics, Heidelberg, v. 40, n. 1, p.71-90, 1999.

ILYAS, M.; BASIR, F. Keefektifan strategi konflik kognitif pada pembelajaran struktur aljabar terhadap kemampuan penalaran dan komunikasi mahasiswa. Pedagogy, Palopo, v. 1, n. 2, p. 28-37, 2016.

LEAL JUNIOR, L. C.; ONUCHIC, L. D. Teaching and learning mathematics through problem solving as sociointeractionist practice. Bolema, Rio Claro, v. 29, n. 53, p. 955-978, 2015.

LODICO, M. G.; SPAULDING, D. T.; VOEGTLE, K. H. Method in educational research: From theory to practice. San Francisco: John Willey \& Sons, 2006.

MAIRING, J. P. Thinking process of naive problem solvers to solve mathematical problems.

International Educational Studies, Ontario, v. 10, n. 1, p. 1-10, 2017.

MAIRING, J. P. Pemecahan masalah matematika: Cara siswa memperoleh jalan untuk berpikir kreatif dan sikap positif. Bandung: Alfabeta, 2018.

MAIRING, J. P. The effect of advance statistics learning integrated minitab and excel with teaching teams. International Journal of Instruction, Turkey, v. 13, n. 2, p, 139-150, 2020.

MAIRING, J. P.; BUDAYASA, I. K.; JUNIATI, D. Profil pemecahan masalah siswa peraih medali OSN Matematika. Jurnal Pendidikan dan Pembelajaran, Malang, v. 18, n. 1, p. 65-71, 2011.

MAIRING, J. P.; SYAHRAN, S.; PANCARITA, P.; SUPARMAN, S. Higher Order Thinking Skills Mahasiswa Pendidikan Matematika dalam Memecahkan Masalah Struktur Aljabar. In: SEMINAR NASIONAL RISET INOVATIF, 6., 2018, Denpasar. Proceedings [...] Denpasar: Undiksha Press, 2018. p. 139-143.

NCTM (NATIONAL COUNCIL OF TEACHERS OF MATHEMATICS). Principles and standards for school mathematics. Reston: The National Council of Teachers of Mathematics, 2000.

OKUR, M.; DIKICI, R.; SANALAN, V. A.; TATAR, E. Computer application in teaching abstract algebra. International Journal of Applied Science and Technology, St. Louis, v. 1, n. 1, p. 20-27, 2011.

POLYA, G. How to solve it. 2 ed. Princeton: Princeton University Press, 1973. 
POLYA, G. Mathematical discovery: On understanding, learning and teaching problem solving. New York: John Wiley \& Sons, 1981.

PRASTITI, T. D. Problem based learning on the learning perseverance of Indonesian senior high school students in solving mathematical problems. Bolema, Rio Claro, v. 34, n. 68, p. 1206-1220, 2020.

RACHMAWATI, L.; INDRARINI, R.; FUAD, R. A.; WULANDARI, M. C.; MULYANTO, J. D. Media pembelajaran video untuk meningkatkan motivasi mahasiswa belajar statistik ekonomi. Equlibria Pendidikan, Semarang, v. 5, n. 1, p. 43-52, 2020.

RAHARJO, R. Pengembangan video tutorial pada mata kuliah pengantar statistika pendidikan untuk pembelajaran e-learning. Jurnal Ilmiah Mimbar Demokrasi, Jakarta, v. 13, n. 2, p. 59-77, 2014.

ROSA, N. M.; PUJIATI, A. Pengaruh model pembelajaran berbasis masalah terhadap kemampuan berpikir kritis dan kemampuan berpikir kreatif. Formatif, Jakarta, v. 6, n. 3, p. 175-183, 2016.

RUTHERFORD, A. Introducing anova and ancova: A GLM approach. London: Sage Publications, 2001.

SALSABILA, E.; RATNANINGSIH, R.; HADI, I. Pembekalan pemahaman metode pembuktian matematika dan penerapan strategi abduktif-deduktif untuk mengembangkan kemampuan membuktikan konsep aljabar abstrak pada mahasiswa jurusan matematika FMIPA UNJ. Jurnal Matematika Integratif, Sumedang, v. 11, n. 1, p. 15-24, 2015.

SARININGSIH, R.; PURWASIH, R. Pembelajaran problem based leearning untuk meningkatkan kemampuan pemecahan masalah matematis dan self efficacy mahasiswa calon guru. Jurnal Nasional Pendidikan Matematika, Cirebon, v. 1, n. 1, p. 163-177, 2017.

SINDU, I. G.; PARAMARTHA, A. A. The effect of the instructional media based on lecture video and slide synchronization system on statistics learning achievement. In: ABDULLAH, A. G.; FOLEY, J.; SURYAPUTRA, I. G. N. A.; HELLMAN, A. (Eds.). Global Conference on Teaching, Assessment, and Learning in Education (GC-TALE 2017). Banyuasri: SHS Web of Conference, 2018. v. 42, p. 1-8.

SKEMP, R. R. The psychology of learning mathematics. Middlesex: Pinguin Books, 1982.

STERNBERG, R. J.; STERNBERG, K. Cognitive psychology. Belmont: Wadsworth, 2012.

SYAFMEN, W. Penerapan pembelajaran team based learning (TBL) untuk meningkatkan prestasi belajar mahasiswa pada mata kuliah struktur aljabar. Sainmatika: Jurnal Sains dan Matematika Universitas Jambi, Jambi, v. 6, n. 1, p. 65-76, 2013.

TALL, D. Reflection on APOS theory in elementary and advanced mathematical thinking. In: ZASLAVSKY, O. (Ed.). Proceedings of 236h Conference of PME. Haifa: publisher, 1999. p. 111118.

WEBER, K. Student difficulty in constructing proofs: The need for strategic knowledge. Educational Studies in Mathematics, Heidelberg, v. 48, n. 1, p. 101-119, 2001.

ZAFFAR, A.; QURAISHI, S. M.; ANSARI, M. R. Teaching of abstract algebra at undergraduate level. The Sindh University Journal of Education, Hyderabad, v. 39, n. 2009-10, p. 1-12, 2013. 